\title{
IMPACT OF AGRICULTURE ON SOIL POLLUTION IN BULGARIA
}

\author{
Hristina Harizanova-Bartos ${ }^{1}$, Zornitsa Stoyanova ${ }^{2}$, \\ *Corresponding author E-mail: h.harizanova@gmail.com
}

A R T I C L E I N F O
Original Article
Received: 25 April 2019
Accepted: 04 June 2019
doi:10.5937/ekoPolj1902375H
UDC 630:332.368(497.2)

Keywords:

Agriculture, mechanisms, pollution, environment, Bulgaria

JEL: Q1, Q5

\begin{abstract}
A B S T R A C T
This article proposes an interpretation of some statistical and empirical evidence of the impact of land pollution on agriculture and agriculture as pollutant. The new conditions concerning the quality of land and land pollution, together with the increasing demand for profitability of traditional agriculture, have led to problems of lack of sufficient farming lands and increased level of degraded soil quality. The land is characterized as a prime production factor in agriculture with own specifications and cadaster. The study emphasizes the contribution of the impact of agriculture on land usage in Bulgaria and the agriculture as affected by soil pollution. The parts of the article are as follows: 1) literature review concerning the connection of the agriculture as a soil/land pollutant and soil/land polluter; 2) Methodology is based on one-dimensional and twodimensional distribution of data collected by own survey. 3) According to the collected data is made analysis and some general conclusions which can be used as policy recommendations.
\end{abstract}

(C) 2019 EA. All rights reserved.

\section{Introduction}

Land is one of our the most precious assets, and its use is multi-facetted, but the new conditions concerning the quality of land and land pollution, together with the increasing demand for profitability of traditional agriculture, have led to problems of lack of sufficient farming lands and increased level of degraded soil quality. The soils perform several functions as biomass production, water quality maintenance, biological habitat, physical infrastructure support, raw materials for human use, and maintaining cultural heritage. Some of these functions can be combined (Blum\& Swaran, 2004). Bruulsema (2018) adds the soils are from significant importance not only for agricultural productivity, but also for the ecosystem services related to quality of water, air, and food. The author consider soils have benefits to human health, provide calories and protein, improves crop quality etc. Functions of the land and their implementation in

1 Hristina Harizanova-Bartos, assoc. prof. dr, UNWE, Sofia, Bulgaria, $+3592 / 8195529$, h.harizanova@gmail.com , ORCID ID https://orcid.org/0000-0001-5731-1326

2 Zornitsa Stoyanova, assoc. prof. dr, UNWE, Sofia, Bulgaria, $+3592 / 8195529$, e-mail: zstoyanova@unwe.bg ORCID ID https://orcid.org/0000-0002-9067-1064

http://ea.bg.ac.rs 
planning sustainable land management includes best practices for reducing the effects of soil processes as degradation and the best practices for land use. One of the purposes of the usage of the land is for agriculture.

Bulgaria is well known with deep traditions in agriculture. The land of agricultural use is formed by arable land, perennial crops, permanent grassland with agricultural use (including highland pastures and grasslands with low productive potential), family gardens and farmland over five years. In 2017, land of agricultural use is $47.1 \%$ of total territory on Bulgaria (MAF, 2017). The sustainable usage of the land and keeping the recourse in good condition can be reached by proper policies and implementing good practices which will reduce the polluted land by agricultural activities.

\section{The agricultural land as affected by pollution and a reason for land pollution}

The land pollution caused by agriculture activities is mainly to the technologies which are used by the farms (Novotny, 1999). The transformation from small farms to agro-businesses structures leads to a revolution in productivity. In a study the author finds the relationship between the transformation of the type of agriculture activities, intensification of the production and population growth. Population size and density determine the demands for food and monetary income (Veldkamp, 1996). The sustainable use of the land is in prime sector for many countries, where they study and measure the quality of lands. The consequences by land pollution can be summarized as follows: degradation by land use conversion, increased erosion and soil loss, chemical pollution by fertilizers and pesticides and pollution from animal operations. Novotny (2005) made a link between the impact of subsidies and the level of polluted lands, explained by the fact that many countries determine what should be grown and how large the farms will be in order to get the highest amount of subsidies (Novotny, 2005). Some authors suggest that with the tightening environmental standards, farmers have to adapt practices in order to reduce the fertilization, restricting grazing time, exporting manure, covering slurry storage, applying slurry through injection into the soil, reducing young stock and restricting feed protein content etc. (Oenema et al., 2011). There is a contradiction between sustainable land use and the need for high input production which requires more energy, fertilizers and irrigation (Winfried et al., 2015). The authors conclude that for measuring land performance and the impact on agriculture further indicators should be included, targeting water resources, biodiversity and the atmosphere. The countries which are big pork and poultry producers with lack of standards or directives to regulate the common practice of adding $\mathrm{Cu}$ to animal feeds are facing problems and have a potential risk of soil copper pollution with animal manure use in agriculture (Xiong et al., 2010). Yooeun \& Youn-Joo (2018) consider mulch from agricultural activities lead also to soil pollution. The authors consider this pollutant influence on soil ecosystem and the problem has been neglected. Pressure on land use and the application of more intensive farming practices, as well as the abandonment of land in some OECD countries creates a risk for landscape conservation. This is due to traditional farming practices, especially in some countries where the landscape is considered for a cultural heritage (OECD, 2004). 
Other authors point that the different production structures are affecting the environment differently and some of them have the potential to modify the conditions, especially those of environment (Vasilescu, Cicea, Popescu, \& Andrei, 2010). Furhermore (Andrei, Mieila \& Panait, 2017; Dusmanescu, Andrei, J., \& Subic (2014) point that the economic of the countries based fundamentally on on energy by fossil fuels, confining resources and issuing emissions. For future decreasing the levels of pollution the agriculture should use more energy from alternative sources.

Agriculture creates a risk for soil erosion through some practices such as land use change, soil treatment or excessive grazing. A large share of the fertile land changes its use and become non-fertile due to intensive agriculture, that lead to erosion and desertification. Agricultural activities contribute to the pollution of soils with toxic substances such as cadmium because of the use of mineral phosphate fertilizers or organic pollutants due to pesticides use (Kanianska, 2016).

The pressure on agricultural land also increased considerably due to the modernization of agriculture and mechanization, which poses a risk for the environment through soil compaction. Excessive use of machines, intensive farming, intensive grazing and inadequate soil management lead to its compaction. Soil contamination problems occur to varying degrees in almost all farming systems around the world. These kind of problems are particularly important when intensive mechanization for soil treatment is used (Soane \& Ouwerker, 1994).

Modern agricultural techniques usually require the use of a large amount of fertilizers. Often many farmers use large quantities of mineral fertilizers or manure to protect young plants. This technique poses a risk for the environment, as young plants are unable to absorb part of the nitrogen. As a result, the nitrogen is released into the environment. This practice causes a breakdown of the acidity of the soil that affects the growth of the plants. If the acidity of the soil is high enough, there is a risk of release of ammonia, which increases the risk of acid rain (Litterman et al., 2003). Phosphate based fertilizers are used in addition to nitrogen fertilizers, which poses also a risk for the environment. Increasing the use of phosphate fertilizers leads to the accumulation of phosphorus in soils. This creates a risk of high concentrations of phosphorus and environmental pollution. Toxic effects of phosphorus are particularly risky for lakes, streams and other water sources as excessive phosphorus leads to eutrophication (Litterman et al., 2003). On the other hand, the result of polluted land is affecting strongly the agriculture. The pollution of the soils by heavy metals is a worldwide problem because these metals are indestructible and most of them have toxic effects on living organisms at certain concentrations (Bhuiyan et al., 2010).

In the scientific research the water pollution is linked with the quality of the soils (National Research Council, 1993). The link is by soil transfer of nitrates, phosphorus, pesticides, and salts from farming systems to surface water and groundwater which leads to loss of soil organic matter and polluted water. 


\section{Materials and methods}

The methodological framework in the study is based on literature finding, according to which is developed a questionnaire. Its aim is to evaluate the agriculture as a land polluter and pollutant. The proposed methodology was already used by evaluating the impact of agriculture on water and air. The gathered information will give the possibility to find the link between the sub branches of agriculture and land pollution. The collected data will show the rank (on sub sectoral level) of the highest land pollutant and the rank of the most affected subsectors from polluted land. The data is a part of scientific project: DN 15/8 11.12. 2017 Sustainable multifunctional rural areas: reconsidering agricultural models and systems with increased demands and limited resources.

The survey was held in 2018, and the interviewed target included agricultural experts among the government services, and non-government organizations as consultant agencies which have the specific knowledge for the effect of land pollution on the agricultural sector, and as well having a deep knowledge and expert view of the technologies in the sector and what is the current impact of the different types of agricultural activities on land pollution. On the other hand, the authors are trying to find specific mechanisms applied in agricultural sector which can bring sustainable land usage and profitable agriculture in Bulgaria. The sample size is 24 and the questionnaire includes closed and open questions. The five step Likert scale were used to evaluate the current condition in the studied topics.

The respondents had a special question which were revealed by the theoretical framework. The interviewed had to evaluated the impact of the agricultural sectors on soil pollution and agriculture as a victim of soil pollution. The main agricultural practices related to plant and livestock breeding are evaluated to find out their negative impact on soil resources. Respondents shared a view about voluntary and restricting measures related to reducing the negative impact of agricultural activities on soils respective to land pollution. The results are rather informative then quantify described and aimed to straighten the current knowledge of the land pollution by experts' own perception to what is the current willingness and readiness to adopt new practices to overcome the negative impact of the pollution. For deeper analysis in the future can be used more sophisticated models (Ren, Louie, and Peter Ren 2018) The framework of the study is presented on the Figure 1. 
Figure 1. Methodological framework

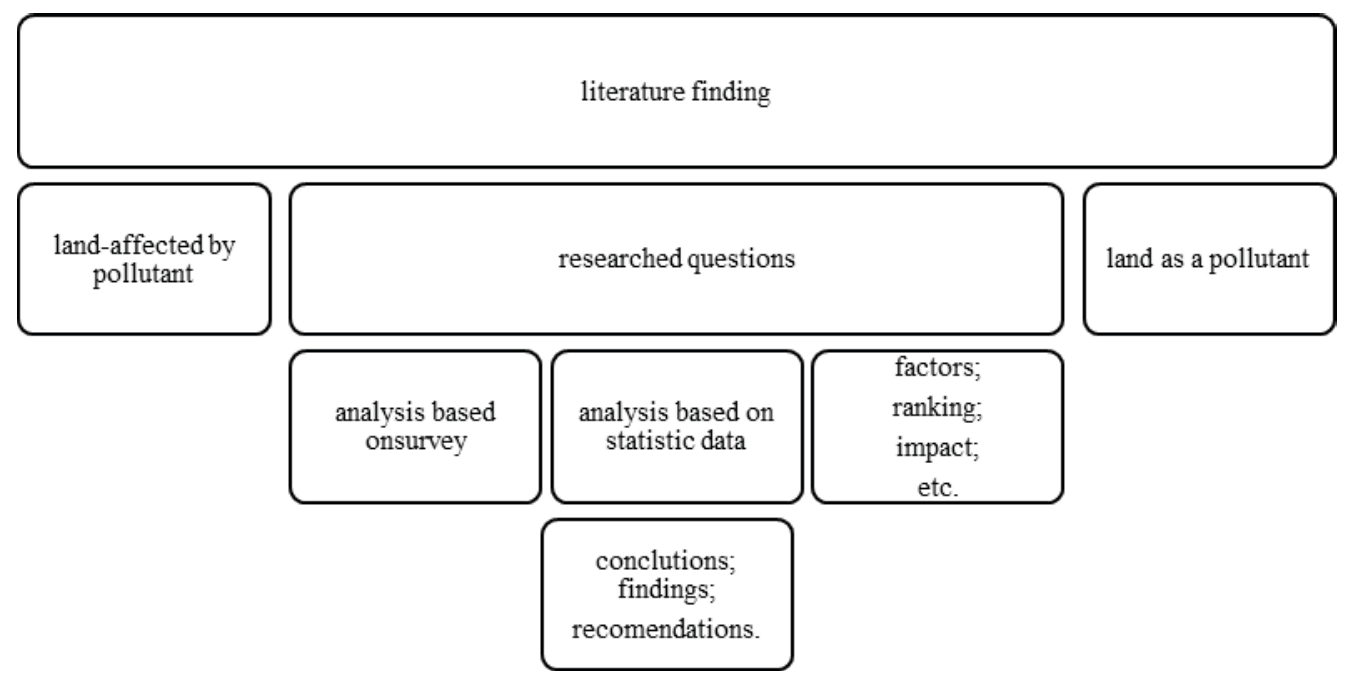

As a final part of the paper some general conclusions are proposed and compartments with sub-related resources.

\section{Results and discussions}

\section{Impact of agriculture on land pollution}

Due to the variety of relief, climatic, plant-geographic and geological conditions there is a wide variety of soils in Bulgaria. During the period 2005 - 2016 the soils in the country are in good ecological condition in terms of pollution with heavy metals, metalloids and persistent organic pollutants. In 2016 fertilizer and manure were used for the area of 4469950 ha, which represents $89 \%$ of the agricultural area during this year. In the same year (2016) 356913 tonnes of nitrogen fertilizers (N), 82566 tonnes of phosphorous fertilizers $\left(\mathrm{P}_{2} \mathrm{O}_{5}\right)$ and 45457 tonnes of potassium fertilizers $\left(\mathrm{K}_{2} \mathrm{O}\right)$ were used in the country. There was an increase in the total amount of used fertilizers compared to 2015 (Figure 2). The increase of the nitrogen fertilizers used in 2016 is $4.5 \%$ more than those used in 2015. An increase of phosphorous fertilizers, amounts $30.7 \%$ in comparison with 2015 . The use of potassium fertilizers $\left(\mathrm{K}_{2} \mathrm{O}\right)$ also increased with $33.26 \%$ from 34112 tonnes used in 2015 to 45457 tonnes in 2016 year. There is also increase in the used quantities of mineral fertilizers in kilograms per hectare (Figure 3). 
Figure 2. Used quantities of mineral fertilizers in Bulgaria, in tones

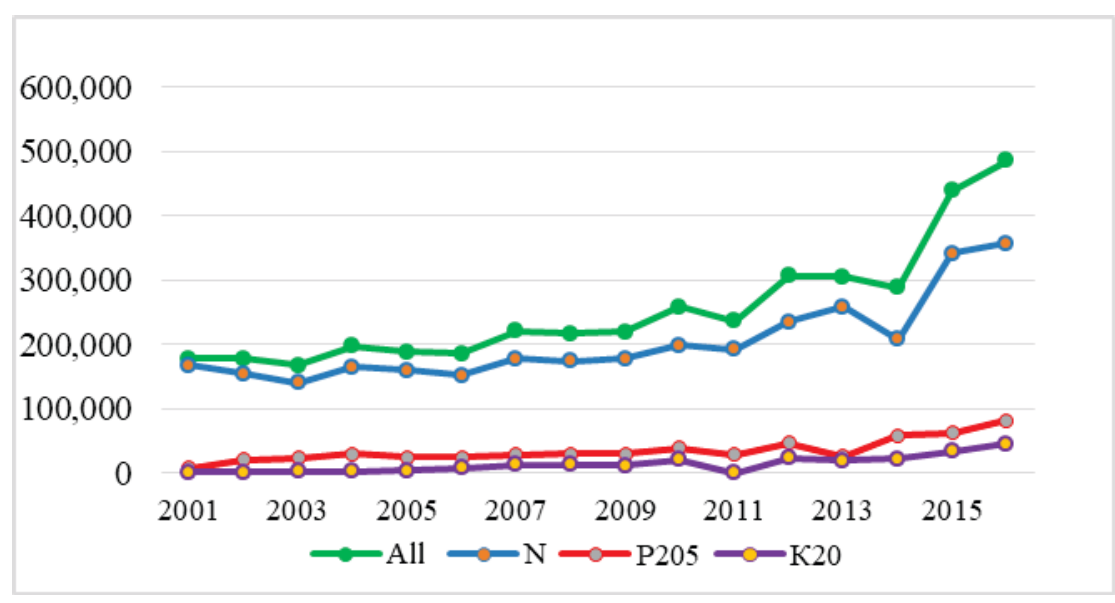

Source: (MEW, 2018)

Figure 3. Used quantities of mineral fertilizers in Bulgaria, $\mathrm{kg} / \mathrm{ha}$

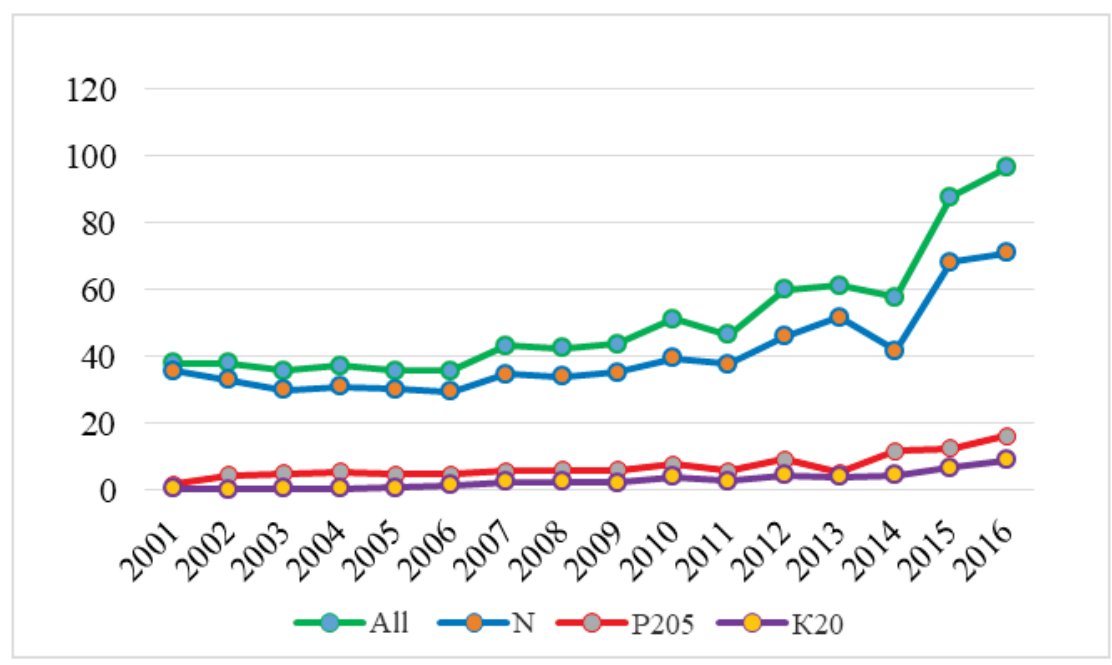

Source: (MEW, 2018)

Regarding the share of arable land treated with mineral fertilizers is established that there is an increase of manured areas 10.3\% more compared to 2015 (total nitrogen and phosphorus). The highest increase of $86 \%$ is recorded for phosphorous fertilizer $\left(\mathrm{P}_{2} \mathrm{O}_{5}\right)$ from 526.3 ha in 2015 to 979 ha in 2016 (Figure 4). 
Figure 4. Share of utilized agricultural area manured with nitrogen and phosphorous fertilizers, $\%$

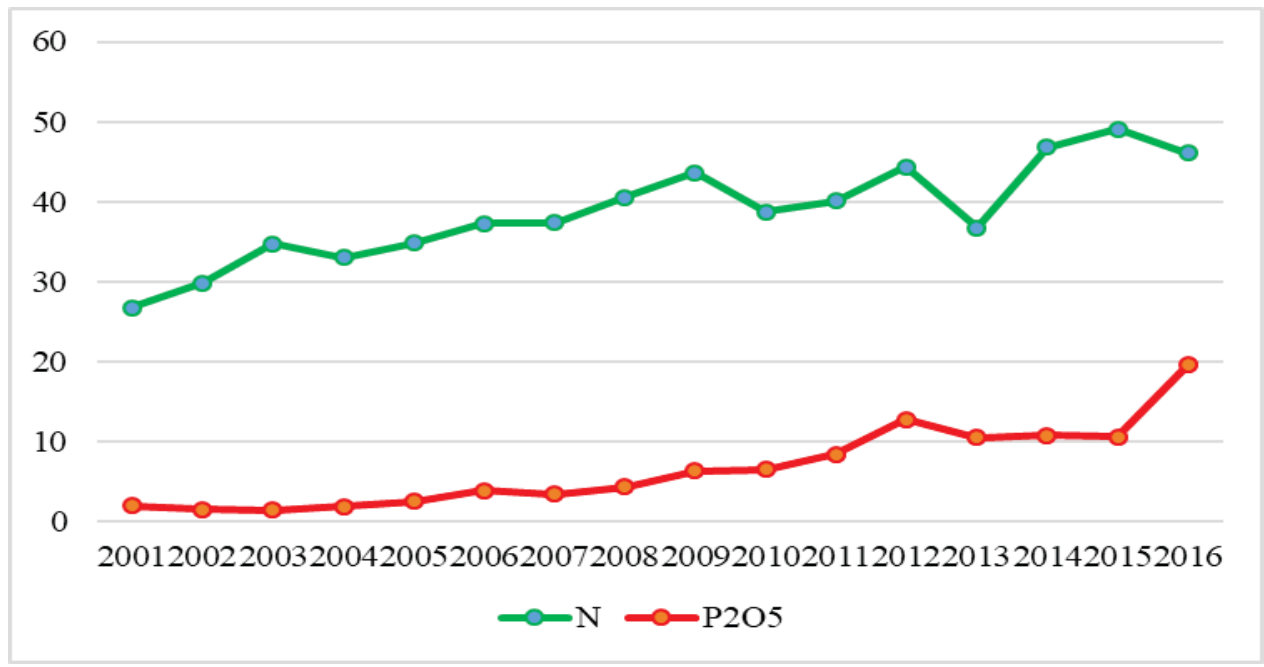

Source: (MEW, 2018)

\section{Analysis of current land pollution and effect on agricultural sector based on own survey}

The main branches in Bulgarian's agriculture are represented in Table 1 where as well is presented the land pollution impact on their development.

Table 1. Sectors affected by land pollution (\%)

\begin{tabular}{|l|l|l|l|l|l|}
\hline Sector & $\begin{array}{l}\text { high } \\
\text { impact }\end{array}$ & $\begin{array}{l}\text { medium-high } \\
\text { impact }\end{array}$ & $\begin{array}{l}\text { medium } \\
\text { impact }\end{array}$ & $\begin{array}{l}\text { low } \\
\text { impact }\end{array}$ & $\begin{array}{l}\text { very low } \\
\text { impact }\end{array}$ \\
\hline Perennials and vines & 17 & 46 & 29 & 4 & 4 \\
\hline Technical cultures & 21 & 21 & 33 & 17 & 8 \\
\hline Grain production & 29 & 25 & 33 & 8 & 4 \\
\hline Oil crops & 33 & 33 & 21 & 8 & 4 \\
\hline $\begin{array}{l}\text { Medical and aromatic } \\
\text { crops }\end{array}$ & 40 & 30 & 25 & 3 & 2 \\
\hline Vegetables & 48 & 32 & 12 & 8 & 0 \\
\hline
\end{tabular}

Source: own survey

The data in table 1 shows very negative impact the polluted soils are having on lands which are with vegetables and medical and aromatic crops. The opinion of the interviewees was that these two branches of agricultural sector are most vulnerable and the production will be with very bad quality and quantity. Second place with $66 \%$ cumulative impact are lands with oil crops, where as well the effect is significant. The perennials and vines are mostly pointed as medium affected by polluted lands. 
Technical cultures are mentioned as the only sub branch which is not heavily affected by presents of pollutant land.

According to the gathered information about the level of polluted land on livestock breeding in Bulgaria the experts evaluated mostly side effects, as lack of grazing land, and the output by the crops.

In the other hand is interesting to examine the opposite influence. As is was argued in the first part of the paper the agricultural sector is negatively effecting the land with all practices and prepares which are used for cropping and livestock breading.

Table 2. Impact on land pollution - plant, \%

\begin{tabular}{|l|c|c|c|c|c|}
\hline \multicolumn{1}{|c|}{ Sector } & high impact & $\begin{array}{c}\text { medium-high } \\
\text { impact }\end{array}$ & $\begin{array}{c}\text { medium } \\
\text { impact }\end{array}$ & low impact & $\begin{array}{c}\text { very low } \\
\text { impact }\end{array}$ \\
\hline $\begin{array}{l}\text { Medical and aromatic } \\
\text { crops }\end{array}$ & 0 & 0 & 0 & 63 & 38 \\
\hline Perennials and vines & 25 & 29 & 29 & 17 & 0 \\
\hline Grain production & 29 & 13 & 38 & 13 & 8 \\
\hline Oil crops & 29 & 25 & 17 & 17 & 13 \\
\hline Vegetables & 33 & 33 & 13 & 8 & 13 \\
\hline Technical cultures & 38 & 38 & 17 & 4 & 4 \\
\hline
\end{tabular}

Source: own survey

From the presented data could be made a conclusion that highest impact is observed by technical cultures and vegetables, where the accumulated percent is accordingly $76 \%$ and $66 \%$ (Table 2). The lowest impact is by medical and aromatic crops, where is pointed no negative impact.

The same measurement is obtained for livestock sector and is shown in Table 3.

Table 3. Impact on land pollution-livestock, \%

\begin{tabular}{|l|c|c|c|c|c|}
\hline Sector & $\begin{array}{l}\text { high } \\
\text { impact }\end{array}$ & $\begin{array}{l}\text { medium-high } \\
\text { impact }\end{array}$ & medium impact & low impact & $\begin{array}{l}\text { very low } \\
\text { impact }\end{array}$ \\
\hline $\begin{array}{l}\text { Cattle-breeding and } \\
\text { buffalo-breeding }\end{array}$ & 67 & 8 & 17 & 4 & 4 \\
\hline $\begin{array}{l}\text { Sheep and goat } \\
\text { breeding }\end{array}$ & 33 & 29 & 21 & 17 & 0 \\
\hline Pig breeding & 33 & 42 & 25 & 0 & 0 \\
\hline Poultry rising & 25 & 42 & 25 & 4 & 4 \\
\hline Beekeeping & 0 & 0 & 0 & 4 & 96 \\
\hline Rabbit breeding & 21 & 21 & 25 & 25 & 8 \\
\hline Horse breeding & 12 & 12 & 50 & 12 & 14 \\
\hline
\end{tabular}

Source: own survey 
Presented data in table 3 reveal the significant impact on land by cattle-breeding and buffalo-breeding, pig breeding and sheep and goat breeding. Cumulative percent of each of these sub branches is above $60 \%$, and the highest pollutant is cattle-breeding and buffalo-breeding with $67 \%$. Less influence on land is by beekeeping and horse breeding.

The experts had to evaluate specific measurements (voluntary - Table 4 and restrictive- Figure 5) which can influence positively by reducing land pollution by agricultural activities.

By the collected data the possible effect is given as middle effect and almost all of the experts forecast middle impact of the chosen practices for evaluation. Investments in irrigation facilities for the optimal use of water resources and protect the soils is the only answer who is pointed as a stronger influence and is around 33\%. The very low scoring ca be explained that these practices have been implemented in Bulgarian agriculture and for the future periods they will not bring high effect then what is already reached.

Table 4. Evaluation of the possible voluntary practices which can reflect on land pollution by agriculture, $\%$

\begin{tabular}{|l|c|c|c|c|c|}
\hline \multicolumn{1}{|c|}{ Practices } & $\begin{array}{c}\text { very low } \\
\text { impact }\end{array}$ & $\begin{array}{c}\text { low } \\
\text { impact }\end{array}$ & $\begin{array}{c}\text { medium } \\
\text { impact }\end{array}$ & $\begin{array}{c}\text { medium-high } \\
\text { impact }\end{array}$ & $\begin{array}{c}\text { high } \\
\text { impact }\end{array}$ \\
\hline $\begin{array}{l}\text { Training of farmers to implement } \\
\text { plant conservation measures }\end{array}$ & 4 & 8 & 50 & 21 & 17 \\
\hline $\begin{array}{l}\text { Development of rules for compliance } \\
\text { with the good agricultural practices }\end{array}$ & 4 & 0 & 58 & 17 & 21 \\
\hline $\begin{array}{l}\text { Policies which motivate the } \\
\text { compliance with the Nitrate Directive }\end{array}$ & 4 & 8 & 33 & 33 & 21 \\
\hline Subsidizing bio products & 8 & 8 & 25 & 38 & 21 \\
\hline $\begin{array}{l}\text { Environmental practices beyond the } \\
\text { standards of traditional agriculture }\end{array}$ & 8 & 17 & 38 & 17 & 21 \\
\hline $\begin{array}{l}\text { Policies which motivate the } \\
\text { application of ecological practices }\end{array}$ & 4 & 0 & 42 & 25 & 29 \\
\hline $\begin{array}{l}\text { Investments in irrigation facilities for } \\
\text { the optimal use of water resources } \\
\text { and protect the soils }\end{array}$ & 4 & 4 & 25 & 33 & 33 \\
\hline
\end{tabular}

Source: own survey

According to obligatory mechanisms the results differ, and is observed more wide answers by the evaluated possibilities. From the shown information in Figure 5, we can conclude that most of the restrictive possibilities will impact on the land pollution. Highly evaluated payment of eco tax for non-compliance with the Nitrate Directive and preparation ecotax (paid by producer). Lowest or almost not further impact the experts evaluated enhanced control over applied farming practices and preparation ecotax (paid by producer). 
Figure 5. Obligatory and restrictive mechanisms

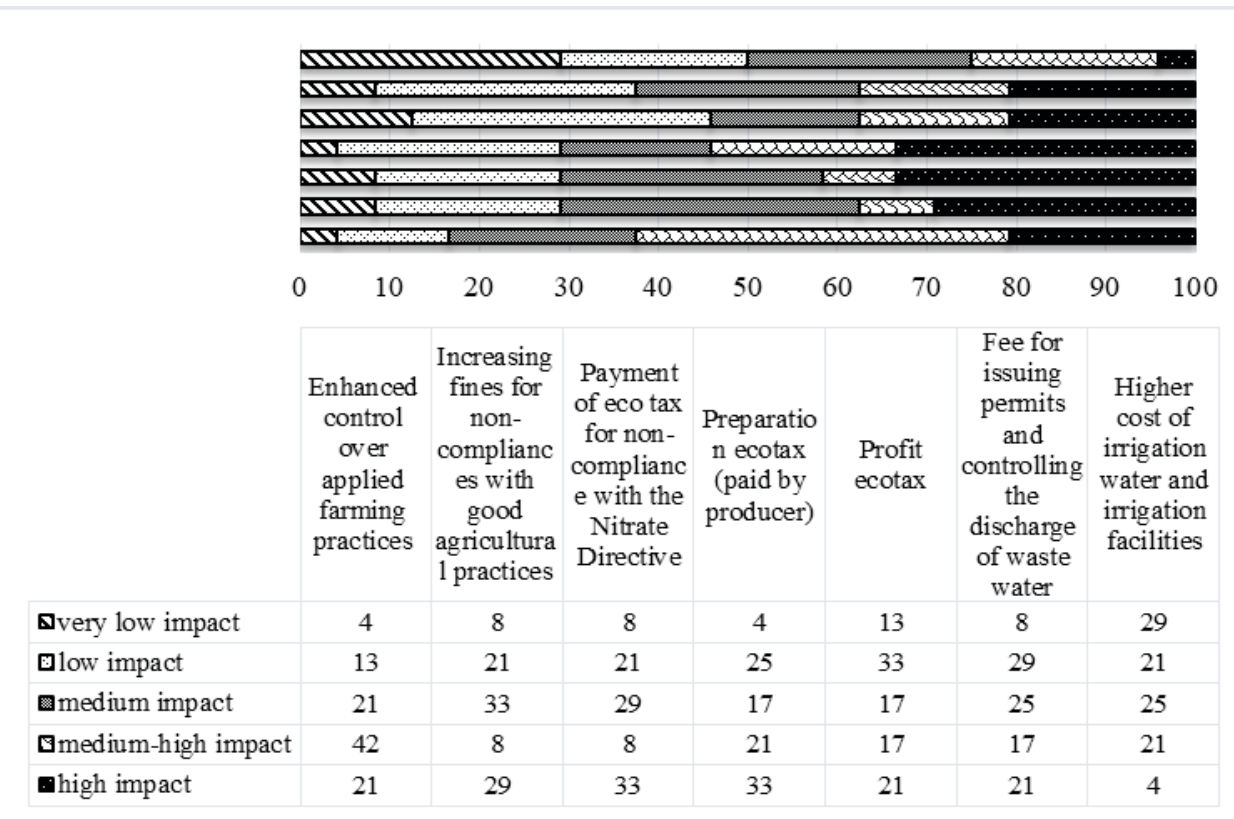

Source: own survey

\section{Conclusions}

On the basis of the conducted study were found the main sources of negative impact on soils arising from agricultural activities, the occurred problems for land and the possible solutions for reducing the negative impact (Figure 6).

Figure 6. Main sources of negative impact on soil related to agricultural activities

\section{Main sources of negative impact on soils related to agricultural activities}
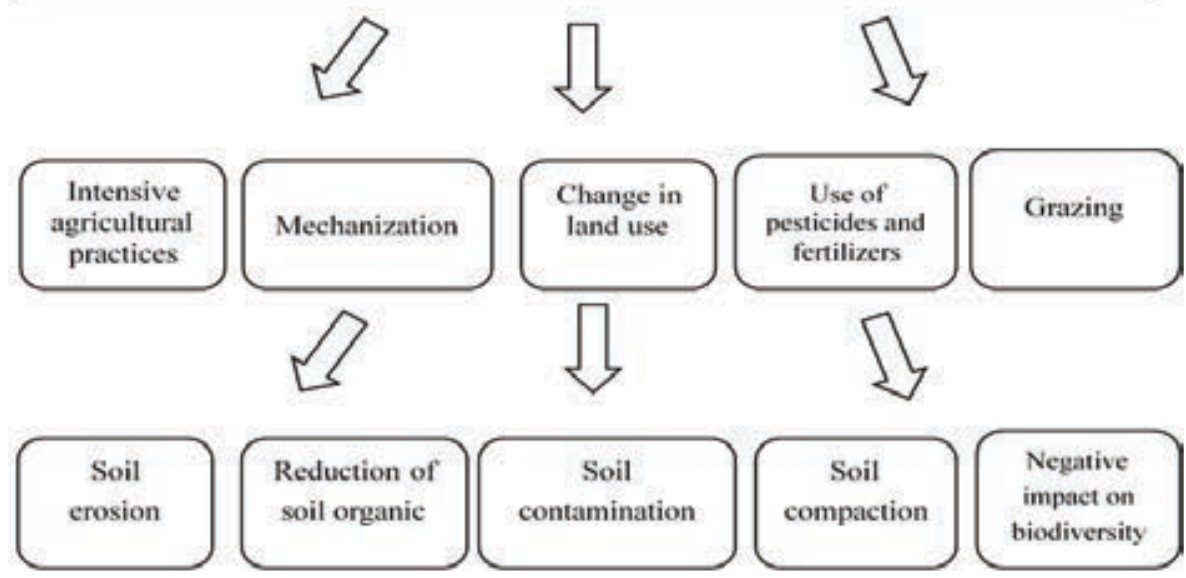
Possible solutions for soil protection from agrarian activities as the reduce of negative impact of contaminated soils on agriculture are related to the following measures: 1) preservation and restoration of soil quality; 2) performing recultivation activities; 3 ) application of control by change in land use. This measures could be realized from the farmers who can be encouraged to apply environmentally friendly and soil-friendly practices through state-compensation mechanisms.

To reduce soil degradation, different farming practices are possible. To limit soil erosion and loss of nutrients, it is necessary to maintain the soil cover. The good state of soil cover can improve soil fertility and reduce the risk of erosion. In this connection, it's possible to use cover crops to reduce soil erosion, green manure crops to help maintain soil organic matter and fertility and intermediate crops to restore residual nutrients to the soil and prevent the loss of nutrients in winter. At the same time, an activity for soil erosion prevention and nutrient loss is the variety of crop rotation and crop combinations that support soil micro-organisms, destroy plant pests, weeds and diseases.

To limit excessive grazing and the negative impact of this process on the soil is necessary to control the size of grazing, and the size must be consistent with the land's carrying capacity. This could be realized through state established requirements as grazing permissions for farmers. Each permit sets months for a grazing for one animal.

Among the possible measures to limit soil contamination is the application of integrated plant protection. In this respect, the use of bio fertilizers will help the increase in soil fertility. For their proper application is necessary the farmers to be informed for the properties of the soils, the physiological characteristics of the cultivated crops and the complex interactions between fertilizer and plants.

In regard to the policies for reducing the soil pollution processes, is important to be applied by the Ministry of agriculture and food control for compliance with good agricultural practices and environmental conditions. At the same time state support for farmers through compensatory payments for activities limiting the degradation and pollution processes is from significant importance.

\section{Acknowledgements}

The findings are part of scientific project DN 15/8 11.12.2017 Sustainable multifunctional rural areas: reconsidering agricultural models and systems with increased demands and limited resources.

\section{Conflict of interests}

The authors declare no conflict of interest. 


\section{References}

1. Andrei, J. V., Mieila, M., \& Panait, M. (2017). The impact and determinants of the energy paradigm on economic growth in European Union. PloS one, 12(3), $\mathrm{e} 0173282$.

2. Bhuiyan, M., Parvez, L., Islam, M., Dampare, S., \& Suzuki, S. (2010). Heavy metal pollution of coal mine-affected agricultural soils in the northern part of Bangladesh. Journal of Hazardous Materials, 173(1-3), 384-392.

3. Blum, W. , \& Swaran, H. (2004). Soils for sustaining global food production. Journal of food science, 69(2), p.37-42.

4. Bruulsema, T. (2018). Managing nutrients to mitigate soil pollution. Environmental pollution, 243 (Part B), 1602-1605. doi:https://doi.org/10.1016/j. envpol.2018.09.132.

5. Dusmanescu, D., Andrei, J., \& Subic, J. (2014). Scenario for implementation of renewable energy sources in Romania. Procedia Economics and Finance, 8, 300-305.

6. Kanianska, R. (2016). Agriculture and Its Impact on Land-Use, Environment,and Ecosystem Services. In A. Almusaed, Landscape Ecology The Influences of Land Use and Anthropogenic Impacts of Landscape Creation. IntechOpen.

7. Litterman, A., Onigbanio, T., \& Soroka, T. (2003). Environmental Impacts of Agriculture. Princeton University.

8. MAF. (2017). Final results for the crops and use of the territory of Bulgaria in 2017, Agrostatistic N:334 [МЗХ,отдел Агростатистика N:334, (2017), БАНСИК 2017 , Окончателни резултати за заетостта и използването на територията на България през 2017] , http://www.mzh.government.bg/MZH/Libraries/ Земя_2017/R_A_334-PublicationBancik2017.sflb.ashx.

9. MEW. (2018). National Report on the Status and Environment of the Republic of Bulgaria. Sofia: MEW. [MOCB. (2018). Национален доклад за състоянието и опазването на околната среда в Република България. София.] http://eеa. government.bg/bg/soer/2016.

10. National Research Council. (1993). An Agenda for Agriculture Soil and water quality: an agenda for agriculture. National Academies Press. ISBN 0-309-049334.

11. Novotny, V. (1999). Diffuse pollution from agriculture-a worldwide outlook. Water Science and Technology, 39(3), 1-13.

12. Novotny, V. (2005). Diffuse pollution from agriculture in the world. In Proceedings from the International Workshop on Where Do Fertilizers Go.

13. OECD. (2004). Agriculture and the Environment: Lessons Learned from a Decade of OECD Work. Paris: OECD Joint Working Party on Agriculture and the Environment. 
14. Oenema, J., Van Keulen, H., Schils, R. L. M., \& Aarts, H. (2011). Participatory farm management adaptations to reduce environmental impact on commercial pilot dairy farms in the Netherlands. NJAS-Wageningen Journal of Life Sciences, 58(12), 39-48.

15. Ren, Louie, and Peter Ren (2018). "Applying a Combined Max-Min Simple Moving Average Trading Strategy to Market Indexes" Economics, Management, and Financial Markets 13(2): 11-23.

16. Soane, B., Ouwerker C. (1994). Soil compaction in crop production. Developments in agricultural engineering, 11.

17. Vasilescu, I., Cicea, C., Popescu, G., \& Andrei, J. (2010). A new methodology for improving the allocation of crops cost production in Romania. Journal of Food, Agriculture and Environment, 8(2), 839-842.

18. Veldkamp, A., \& Fresco, L. (1996). CLUE: a conceptual model to study the conversion of land use and its effects. Ecological modelling, 85(2-3), 253-270.

19. Winfried E., Jasmin, S., \& Georg, J. (2015). European land resources for the sustainable intensification of agriculture, Digital book of proceedings, Soil And Agrotechnology In A Changing World, Published by ISSAPP "Nikola Pushkarov" ISBN: 978-619-90560-0-4,13-17.

20. Xiong, X., Yanxia, L., Wei, L., Chunye, L., Wei, H., \& Ming, Y. (2010). Copper content in animal manures and potential risk of soil copper pollution with animal manure use in agriculture. Resources, Conservation and Recycling, 54(11), 985 990.

21. Yooeun, Ch., Youn-Joo, A. (2018). Current research trends on plastic pollution and ecological impacts on the soil ecosystem: A review. Environmental pollution, 240, 387-395. doi:https://doi.org/10.1016/j.envpol.2018.05.008. 